\title{
Лайпанова Ф.М.
}

\section{Купирование воспаления в периодонте и оптимизация репаративного остеогенеза при альвеолите}

\author{
Lypanova F.M. \\ Relief of inflammation in periodontal and optimization \\ of reparative osteogenesis in the alveolitis
}

Разработан способ альвеолопластки при лечении острого альвеолита. Под наблюдением находилось 149 больных с острым альвеолитом в возрасте от 24 до 65 лет. Способ показал высокую эффективность по сравнению с традиционной методикой, что выразилось в снижении послеоперационных осложнений, сокращении периода выздоровления больных и восстановлении костной архитектоники в области постэкстракционных дефектов челюстей

Ключевые слова: альвеолит, атрофия, воспаление

\section{Лайпанова Фериде Мекеровна}

Аспирант

Ставропольский государственный медицинский университет

2. Ставрополь, ул. Мира, 310
The developed method alveoloplasty in the treatment of acute alveolitis. Under observation there were 149 patients with acute alveolitis in age from 24 to 65 years. The method showed high efficiency compared to traditional methods that resulted in the reduction of postoperative complications, reducing the recovery period of patients and the recovery of bone architectonics in the field of postextraction defects of the jaws

Key words: alveolitis, atrophy, inflammation

\author{
Lypanova Feride Mikerovna \\ Graduate \\ Stavropol state medical university \\ Stavropol, Mira st., 310
}

Альвеолит является одним из наиболее распространенных и часто встречающихся осложнений после операции удаления зуба $[4,6,10,11,19,23]$. По данным ряда исследователей, частота возникновения альвеолита составляет от 13,4 до 42,8\% от всех постэкстракционных осложнений $[3,5,13,20,28]$. Большинство исследователей выделяют в этиологии развития альвеолита инфекционный $[1,2,12,26,34]$ и травматический факторы $[14,18,22,36,45]$. Развитию альвеолита способствует также высокая фибринолитическая активность тканей лунки $[39,40,47]$, слюны, иммунологические сдвиги, сопутствующие заболевания [15,21,30]. Анализ литературы показал, что существующие способы лечения хронического альвеолита однотипны и однонаправлены: ликвидацию воспаления в лунке определяют обязательная хирургическая обработка $[16,23,32,41]$, фармако- и физиотерапевтические методы $[8,17,25]$, а также по возможности одномоментная пластика костного дефекта остеопластическими материалами [24]. Вместе с этим, подобная врачебная тактика при лечении острого альвеолита недостаточно эффективна, поскольку на первый план в тактике врача- 
стоматолога-хирурга выходит не столько профилактика атрофии альвеолярного отростка челюсти, сколько купирование острого воспалительного процесса за счет использования противовоспалительных $[27,35,44]$, антибактериальных и десенсибилизирующих средств [7,38,46], вводимых как внутрь, так и непосредственно в лунку удаленного зуба $[9,29,43]$. Кроме этого, существующими методиками лечения не предусмотрена полноценная изоляция раны от полости рта, что в случае недостаточной гигиены $[31,42]$ нередко приводит к обострению заболевания [33,37].

Цель исследования: разработка и клиническое обоснование способа альвеолопластики при остром альвеолите, обеспечивающем сокращение сроков лечения данной категории больных за счет купирования воспаления и профилактики прогрессирующей атрофии костной ткани.

Материал и методы исследования. Всего под наблюдением находилось 149 больных с острым альвеолитом в возрасте от 24 до 65 лет, из них 87 женщин и 60 мужчин. Всего было удалено 178 зубов, основной причиной альвеолита послужили хронический периодонтит «причинного» зуба в стадии обострения и сложное удаление ретенированного дистопированного третьего моляра. На верхней челюсти острый альвеолит наблюдали у 94 человек $(63,1 \%)$, на нижней - у 55 больных (36,9\%), причем у 107 человек (71,8\%) альвеолит развился после удаления зуба по поводу обострения хронического периодонтита, а у 42 больных $(28,2 \%)$ - после удаления ретенированного дистопированного третьего моляра.

В зависимости от выбранного способа лечения все больные были разделены на 2 группы: основную из 92 больных $(61,7 \%)$ и контрольную, которую составили 57 пациентов $(38,3 \%)$.

Лечение больных в основной группе проводилось по следующей методике (Положительное решение на выдачу патента РФ на изобретение по заявке №2009138723/14 (054826) «Способ лечения и профилактики альвеолита»): под местной инфильтрационной анестезией мобилизовали слизистые края лунки вокруг «причинного» зуба, полностью удаляли из лунки остатки тромба. Затем костную рану обрабатывали в течение 5 минут с помощью волновода от аппарата «Оптодан», с полупроводниковым лазерным диодом, генерирующем импульсный свет с длиной волны от 0,85 до 0,98 мкм, импульсной мощностью 2-4 Вт, длительностью импульса 40-100нс, с частотой импульсов - 1,5-2,0 кГц, напряженностью магнитного поля 35 мТл через 0,05\% раствор мирамистина. Костный дефект обильно промывали смесью 30\% раствора линкомицина гидрохлорида и 1\% раствора диоксидина в соотношении 3:1, высушивали с помощью стерильной коллагеновой губки, заполняли остеопластическим материалом «Коллост» (ЗАО «Биофармхолдинг») на основе деминерализованного и лиофилизированного костного коллагена, прикрывали рану биорезорбируемой мембраной «Коллост» (ЗАО «Биофармхолдинг»), пленкой «Диплен-дента» с линкомицином, после чего ушивали слизистые края лунки наглухо. При дефиците слизистой в области лунки производили пластику по вышеописанной методике с использованием слизисто-надкостничного лоскута. В послеоперационном периоде использовали лазеротерапию аппаратом «Оптодан» - первые 5 процедур 
на 1-м канале с экспозицией 2 мин, затем 5 процедур - на 2-м канале с той же экспозицией по 2 мин в течение 3-4 дней.

В контрольной группе после обезболивания и удаления остатков тромба проводили медикаментозную обработку лунки и вводили в нее йодоформную смесь на марлевой турунде (55\% больных контрольной группы) или препарат «Альвеост» (ЗАО «Полистом») - 45\% больных контрольной группы.

Послеоперационная медикаментозная терапия в обеих группах включала: «Рокситромицин» по 150 мг 2 раза в сутки в течение 3-4 дней, «Цетрин» по 0,2 мг 3 раза в сутки в течение 3-4 дней.

Эффективность лечения в ближайшие и отдаленные сроки наблюдения оценивали по объективным (осмотр и пальпация) и субъективным (жалобы) данным, количеству посещений, данным рентгенологического исследования.

Результаты исследования. Проведенные исследования показали, что у 97,5\% больных основной группы уже к концу первых суток после начала лечения был полностью купирован болевой синдром, гиперемия и отек слизистой оболочки в области лунки «причинного» зуба значительно уменьшались. В контрольной группе исчезновение указанных симптомов у 98,3\% больных наблюдалось, в среднем, на 2,3 $\pm 1,05$ суток позже, чем в основной группе, причем у $1,7 \%$

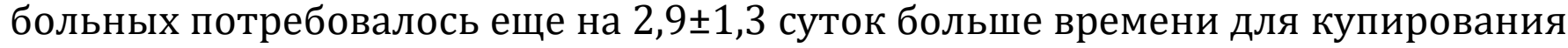
данных клинических признаков, а смена турунд проводилась не менее 3-4 раз в течение 5-6 дней. Число посещений на одного больного в основной группе со-

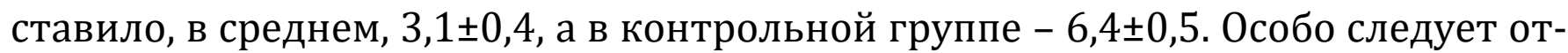
метить тот факт, что рецидива заболевания ни в основной, ни в контрольной группе отмечено не было.

Анализируя отдаленные результаты лечения, полученные в течение 2 лет наблюдений, было установлено, что в основной группе атрофии альвеолярного отростка верхней и альвеолярной части нижней челюсти не наблюдалось. В контрольной группе указанные явления атрофии носили умеренно выраженный характер у 57,6\% больных, резко выраженный характер у 40,2\% больных, у 2,2\% пациентов атрофии не наблюдалось.

Заключение. Таким образом, предлагаемый способ альвеолопластики при остром альвеолите показал свою эффективность по сравнению с традиционной методикой, что выразилось в снижении послеоперационных осложнений, сокращении периода выздоровления больных и восстановлении костной архитектоники в области постэкстракционных дефектов челюстей. Полученные результаты позволяют рассматривать разработанный способ лечения острого альвеолита как метод выбора, высокоэффективный и вполне обоснованный для широкого использования в практике.

\section{Список используемых источников:}

1. Будзинский Н.Э., Сирак С.В., Максимова Е.М., Сирак А.Г. Определение антимикробной активности мирамистина, иммобилизованного на композиционном полисорбе, на микрофлору корневых каналов при остром и обострившемся хроническом периодонтите и процесс остеофикации в эксперименте на животных // Фундаментальные исследования. 2013. №7-3. С. 518-522. 
2. Будзинский Н.Э., Сирак С.В. Особенности лечения хронического верхушечного периодонтита с использованием мирамистина, иммобилизованного на композиционом полисорбе //

Современные проблемы науки и образования. 2013. №3. С. 133.

3. Быков И.М., Сирак А.Г., Сирак С.В. Апробация нового зубного эликсира для профилактики кариеса зубов в условиях эксперимента // Современные проблемы науки и образования. 2013. № 4. С 128. 4. Григорьянц Л.А., Сирак С.В. Лечение травм нижнеальвеолярного нерва, вызванных выведением пломбировочного материала в нижнечелюстной канал // Клиническая стоматология. 2006. № 1. C. 52-57.

5. Григорьянц Л.А., Герчиков Л.Н., Бадалян В.А., Сирак С.В., Григорьяни А.Г. Использование препарата Цифран СТ в хирургической стоматологии для лечения и профилактики послеоперационных воспалительных осложнений // Стоматология для всех. 2006. № 2. С. 14-16.

6. Григорьяни Л.А., Сирак С.В., Зекерьяев Р.С., Арутюнян К.Э. Показания и эффективность использования различных хирургических вмешательств при лечении больных с одонтогенным гайморитом, вызванным выведением пломбировочного материала в верхнечелюстной синус // Стоматология. 2007. T. 86. №3. С. 42-46.

7. Григорьян А.А., Сирак С.В., Сирак А.Г., Ханова С.А. Разработка и клиническое применение нового ранозаживляющего средства для лечения заболеваний слизистой оболочки полости рта у детей и подростков // Современные проблемы науки и образования. 2013. № 2. С.41.

8. Коробкеев А.А., Сирак С.В., Копылова И.А. Изучение особенностей анатомо-топографического строения нижней челюсти для планирования эндодонтического и имплантологического лечения // Медицинский вестник Северного Кавказа. 2010. T.17. № 1. С. 17-22.

9. Максимова Е.М., Сирак С.В. Анализ рисков и мер по профилактике профессиональных болезней врачей-стоматологов // Фундаментальные исследования. 2013. № 5-2. С. 319-323.

10. Рубцова Н.Г., Сирак С.В., Сирак А.Г. Индивидуальная гигиена полости рта и микроскопическая оценка структуры щетинок зубных щеток при их ежедневном использовании // Эндодонтия Тодау. 2013. № 3. C. 68-72.

11. Сирак С.В., Слетов А.А., Локтионова М.В., Локтионов В.В., Соколова Е.В. Диагностика, лечение и профилактика верхнечелюстного синусита, возникающего после эндодонтических вмешательств // Пародонтология. 2008. № 3. С. 14-18.

12. Сирак А.Г., Сирак С.В. Динамика репаративного дентиногенеза после лечения глубокого кариеса и острого очагового пульпита разработанной поликомпонентной лечебной пастой // Фундаментальные исследования. 2013. № 5-2. С. 384-388.

13. Сирак С.В., Шаповалова И.А., Пугина Ю.Н., Лолаева А.К., Афанасьева О.В., Локтионова М.В. Особенности выбора антимикробных препаратов для местного лечения воспалительных заболеваний пародонта у детей и подростков // Стоматология детского возраста и профилактика. 2008. T.7. № 4. C. 61-63.

14. Сирак С.В., Шаповалова И.А., Копылова И.А. Осложнения, возникающие на этапе пломбирования корневых каналов зубов, их прогнозирование и профилактика // Эндодонтия Today. 2009. №1. C. 23-25. 15. Сирак С.В., Сирак А.Г., Копылова И.А., Бирагова А.К. Изучение морфологических изменений в пульпе зубов экспериментальных животных при лечении глубокого кариеса и острого очагового пульпита // Медицинский вестник Северного Кавказа. 2011. Т. 23. №3. С. 29-33.

16. Сирак С.В., Щетинин Е.В., Слетов А.А. Субантральная аугментация пористым титаном в эксперименте и клинике // Стоматология. 2016. Т.95. №1. С.55-58.

17. Сирак С.В., Копылова И.А. Вопросы повышения качества эндодонтических вмешательств по данным анкетирования врачей-стоматологов // Вестник Смоленской государственной медицинской академии. 2010. №2. С. 127-129.

18. Сирак С.В., Быков И.М., Сирак А.Г., Акопова Л.В. Профилактика кариеса и воспалительных заболеваний пародонта с использованием зубных эликсиров // Кубанский научный медицинский вестник. 2013. №6(141). C. 166-169.

19. Сирак С.В., Григорьянц Л.А., Федурченко А.В., Михайленко А.А. Способ оперативного доступа к нижнечелюстному каналу // Патент на изобретение RUS 2326619 09.01.2007

20. Сирак С.В., Коробкеев А.А., Шаповалова И.А., Михайленко А.А. Оценка риска осложнений эндодонтических манипулящий на основе показателей анатомо-топографического строения нижней челюсти // Эндодонтия Today. 2008. №2. С. 55-60.

21. Сирак С.В., Шаповалова И.А., Максимова Е.М., Пригодин С.Н. Стоматологическая заболеваемость детского населения Ставропольского края до и после внедрения программы профилактики // Стоматология детского возраста и профилактика. 2009. Т. 8. № 1. С. 64-66. 
22. Сирак С.В., Казиева И.Э., Мартиросян А.К. Клинико-экспериментальное использование остеопластических материалов в сочетании с электромагнитным излучением для ускорения регенерации костных дефектов челюстей // Фундаментальные исследования. 2013. № 5-2. C. 389-393.

23. Сирак С.В., Чеботарев В.В., Сирак А.Г., Григорьян А.А. Опыт использования местных ранозаживляющих средств при лечении вульгарной пузырчатки с локализацией на слизистой оболочке полости рта и губах // Медицинский вестник Северного Кавказа. 2013. Т. 8. № 1. С. 59-62. 24. Сирак С.В., Шаповалова И.А., Локтионова М.В., Лолаева А.К. Изучение эффективности ранозаживляющего средства для лечения заболеваний слизистой оболочки полости рта у детей и подростков // Стоматология детского возраста и профилактика. 2008. T. 7. № 2. С. 79-81. 25. Сирак С.В. Стоматологическая заболеваемость взрослого населения основных климатогеографических зон Ставропольского края // Диссертация на соискание ученой степени кандидата медицинских наук / Ставропольская государственная медицинская академия. Ставрополь, 2003.

26. Сирак А.Г., Сирак С.В. Профилактика кариеса зубов и воспалительных заболеваний пародонта с использованием зубных эликсиров // Современные проблемы науки и образования. 2013. № 4. С. 110. 27. Сирак С.В., Слетов А.А., Мартиросян А.К., Ибрагимов И.М., Перикова М.Г. Использование пористого титана для субантральной аугментации кости при дентальной имплантации (экспериментальное исследование) // Медицинский вестник Северного Кавказа. 2013. Т. 8. № 3. С. 42-44.

28. Сирак С.В., Долгалев А.А., Слетов А.А., Михайленко А.А. Изучение особенностей анатомотопографического строения нижней челюсти для планирования эндодонтического и имплантологического лечения // Институт стоматологии. 2008. T. 2. № 39. С. 84-87.

29. Сирак А.Г., Сирак С.В. Морфофункциональные изменения в пульпе зубов экспериментальных животных при лечении глубокого кариеса и острого очагового пульпита с использованием разработанных лекарственных композиций // Современные проблемы науки и образования. 2013. № 2. C.44.

30. Сирак С.В., Слетов А.А., Алимов А.Ш., Цховребов А.Ч., Федурченко А.В., Афанасьева О.В. Клиникоэкспериментальное обоснование применения препарата Коллост и биорезорбируемых мембран Диплен-гам и Пародонкол при удалении ретенированных и дистопированных нижних третьих моляров // Стоматология. 2008. Т. 87. №2. С. 10-14.

31. Сирак С.В., Копылова И.А., Чеботарев В.В., Аль-асфари Ф.М.С. Использование поликомпонентной адгезивной мази в сочетании с иммуномодулирующим препаратом в комплексной терапии пузырчатки // Пародонтология. 2012. Т. 17. № 2. С. 62-65.

32. Сирак С.В., Федурченко А.В., Сирак А.Г., Мажаренко Т.Г. Способ лечения радикулярной кисты челюсти // Патент на изобретение RUS 2326648 09.01.2007.

33. Сирак С.В., Ибрагимов И.М., Кодзоков Б.А., Перикова М.Г. Способ субантральной аугментации кости для установки дентальных имплантатов при атрофии альвеолярного отростка верхней челюсти // Патент на изобретение RUS 2469675 09.11.2011.

34. Сирак С.В. Клинико-анатомическое обоснование лечения и профилактики травм

нижнеальвеолярного нерва, вызванных выведением пломбировочного материала в нижнечелюстной канал // Диссертация на соискание ученой степени доктора медицинских наук / ФГУ "Центральный научно-исследовательский институт стоматологии". Москва, 2006

35. Щетинин Е.В., Сирак С.В., Батурин В.А., Сирак А.Г., Игнатиади О.Н., Вафиади М.Ю., Петросян Г.Г., Паразян Л.А., Дыгов Э.А., Арутюнов А.В., Цховребов А.Ч. Результаты мониторинга потребления противомикробных препаратов в амбулаторной практике // Медицинский вестник Северного Кавказа. 2015. T. 10. № 1 (37). C. 80-84.DOI: 10.14300/mnnc.2015.10013

36. Щетинин Е.В., Сирак С.В., Игнатиади О.Н., Сирак А.Г., Демурова М.К., Дыгов Э.А. Экспериментальнолабораторное обоснование выбора антибактериальных средств для лечения периодонтита // Медицинский вестник Северного Кавказа. 2014. T. 9. № 4 (36). С. 349-351.

37. Grimm W.D., Dannan A., Giesenhagen B., Schau I., Varga G., Vukovic M. A., Sirak S.V. Translational research: palatal-derived ecto-mesenchymal stem cells from human palate: a new hope for alveolar bone and craniofacial bone reconstruction // International Journal of Stem Cells. 2014. 7(1). P.23-29.

38. Grimm, W.-D., Ploger M., Schau I., Vukovic M.A., Shchetinin E.V., Akkalaev A.B., Avanesian R.A., Sirak S.V. Complex, three-dimensional reconstruction of critical size defects following delayed implant placement using stem cell-containing subepithelial connective tissue graft and allogenic human bone blocks for horizontal alveolar bone augmentation: a case report as proof of clinical study principles // Medical news of North Caucasus. 2014. № 2(9). P. 125-127. DOI: 10.14300/mnnc.2014.09037. 
39. Grimm W. D., Ploger M., Schau I., Vukovic M.A., Shchetinin E., Akkalaev A. B., Arutunov A.V., Sirak S.V. Prefabricated $3 d$ allogenic bone block in conjunction with stem cell-containing subepithelial connective tissue graft for horizontal alveolar bone augmentation: case report as proof of clinical study principles // Медицинский вестник Северного Кавказа. 2014. № 2(34). C. 175-178.

40. Mikhalchenko D.V., Poroshin A.V., Mikhalchenko V.F., Firsova I.V., Sirak S.V. Influence of transcranial electrostimulation on the osseointegration of dental implant in the experiment // Research Journal of Pharmaceutical, Biological and Chemical Sciences. 2014. T.5. № 5. C.705-711.

41. Grimm W.D., Arnold W.A., Sirak S.W., Vukovich M.A., Videra D., Giesenhagen B. Clinical, radiographic, and histological analyses after transplantation of crest-related palatal-derived ectomesenchymal stem cells (paldscs) for improving vertical alveolar bone augmentation in critical size alveolar defects //Journal of Clinical Periodontology. 2015; 42 (S17): 366b-366.

42. Sirak S.V., Avanesyan R.A., Akkalaev A.B., Demurova M.K., Dyagtyar E.A., Sirak A.G. Microbiocenosis of oral cavity in patients with dental implants and over-dentures // Research Journal of Pharmaceutical, Biological and Chemical Sciences. 2014. T.5. № 5. C.698-704.

43. Sirak S.V., Arutyunov A.V., Shchetinin E.V., Sirak A.G., Akkalaev A. B., Mikhalchenko D.V. Clinical and morphological substantiation of treatment of odontogenic cysts of the maxilla // Research Journal of Pharmaceutical, Biological and Chemical Sciences. 2014. T.5. № 5. C.682-690.

44. Sirak S.V., Shchetinin E.V. Prevention of complications in patients suffering from pathological mandibular fractures due to bisphosphonate-associated osteonecroses // Research Journal of Pharmaceutical, Biological and Chemical Sciences. 2015. T.6. № 5. C.1678-1684.

45. Sirak S.W., Entschladen F., Shchetinin E.W., Grimm W.D. Low-level laser irradiation (810 nm) with toluidinblue photosensitizer promotes proliferation and differentiation of human oral fibroblasts evaluated in vitro. Journal of Clinical Periodontology // 2015. T. 42. № S17. C. 328a-328.

46. Sirak S.V., Avanesyan R.A., Sirak A.G., Shchetinin E.V., Demurova M.K. Social composition and motivation of patients in applying for implant dental service // Research Journal of Pharmaceutical, Biological and Chemical Sciences. 2014. T. 5. № 5. C. 691-697.

47. Shchetinin E.V., Sirak S.V., Khodzhayan A.B., Dilekova O.V., Sirak A.G., Vafiadi M.Yu., Parazyan L.A., Arutyunov A.V. Pathogenetic aspects of dental pulp pathology // Медищинский вестник Северного Кавказа. 2015. T. 10. № 2 (38). C. 187-191.

48. Firsova I.V., Makedonova Iu.A., Mikhalchenko D.V., Poroiskii S.V., Sirak S.V. Clinical and experimental study of the regenerative features of oral mucosa under autohemotherapy // Research Journal of Pharmaceutical, Biological and Chemical Sciences. 2015. T. 6. №6. C. 1711-1716.

(C) 2016, Лайпанова Ф.М.

Купирование воспаления в периодонте и оптимизация репаративного остеогенеза при альвеолите
(C) 2016, Lypanova F.M.

Relief of inflammation in periodontal and optimization of reparative osteogenesis in the alveolitis 